\title{
AKUNTABILITAS PADA LEMBAGA AMIL ZAKAT INFAK DAN SEDEKAH DALAM PERSPEKTIF SHARI'AH ENTERPRISE THEORY (SET)
}

\author{
Hetty Hikmaningsih ${ }^{*}$, Bambang Agus Pramuka ${ }^{1}$ \\ ${ }^{1}$ Program Pascasarjana Magister Akuntansi, Fakultas Ekonomi dan Bisnis, Universitas Jenderal \\ Soedirman, Indonesia \\ ${ }^{*}$ Email corresponding : hetty.hikmaningsih@gmail.com
}

\begin{abstract}
Abstrak
Akuntabilitas Lembaga Amil Zakat Infak dan Sedekah menjadi sangat penting untuk mendorong kepercayaan publik terhadap lembaga tersebut. Penelitian ini bertujuan menjelaskan implementasi akuntabilitas pada lembaga amil zakat, infak, sedekah dalam perspektif Shari'ah Enterprise Theory. Konsep SET membawa pemahaman yang holistik tentang akuntabilitas Lazis baik dari dimensi habluminallah dan hablumminannas. Metode penelitian yang digunakan adalah kualitatif studi literatur (literature review). Sumber rujukan penelitian ini adalah penelitian terdahulu mengenai praktik akuntabilitas LAZIS. Penelitian ini menunjukkan bahwa praktik akuntabilitas Lazis mencakup dimensi habluminaallah dan habluminannas. Praktik akuntabilitas Lazis dimanifestasikan menjadi aspek fisik berupa pertanggungjawaban laporan keuangan sesuai PSAK 109. Aspek mental dan spiritual diwujudkan dalam berbagai program baik dalam bidang ekonomi maupun sosial, serta etika karyawan dan ketaatan karyawan terhadap syariat Islam.
\end{abstract}

Kata Kunci : Akuntabilitas, SET, Lazis

\begin{abstract}
The accountability of the Amil Zakat, Infak and Shadaqa institution needed to improve the public trust. This study aims to explain the implementation of accountability in amil zakat, infaq and shadaqa institutions in the perspective of Shari'ah Enterprise Theory. SET concept brings a holistic understanding of both dimensions of accountability Lazis, habluminallah and hablumminannas.The research method used is a qualitativeliterature review. The reference source of this study is previous research on LAZIS accountability practices. This research shows that accountability practices of Lazis includes the hablumniallah and habluminannas dimensions. Lazis accountability practice is manifested in physical aspects in the form of accountability for financial statements in accordance with PSAK 109. Mental and spiritual aspects are manifested in various programs both in the economic and social fields, as well as employee ethics and employee obedience to Islamic law.
\end{abstract}

Keywords : Accountability, SET, Lazis

\section{PENDAHULUAN}

Zakat adalah 5 pilar dalam agama Islam. Zakat adalah kewajiban yang bersifat fundamental yang berkaitan dengan aspek ketuhanan, ekonomi maupun sosial. Al-Quran telah menyebutkan ayat-ayat yang menjelaskan kewajiban zakat yang disandingkan dengan sholat. Zakat wajib ditunaikan oleh setiap muslim yang telah mencapai nishob dengan cara dijemput oleh lembaga amil. Menurut Undang-Undang No. 23 Tahun 2011, zakat adalah harta yang wajib dikeluarkan oleh seorang Muslim atau badan usaha untuk diberikan kepada yang berhak menerimanya sesuai dengan syariat Islam. Dalam UU tersebut disebutkan bahwa tujuan dari zakat adalah untuk mewujudkan kesejahteraan masyarakat, meningkatkan keadilan sosial dan penanggulangan kemiskinan sehingga diharapkan di masyarakat tidak terjadi gap atau kesenjangan yang tinggi antara si kaya dengan si miskin. Menurut PSAK No. 109, tujuan zakat 
yang mulia tersebut akan dapat tercapai apabila dalam pengelolaan zakat dilakukan secara baik dan professional (good zakat governance), artinya bahwa zakat seharusnya dikelola secara melembaga sesuai dengan syariat Islam, amanah, kemanfaatan, keadilan, kepastian hukum, terintegrasi, dan akuntabilitas.

Dalam Undang Undang No.23 Tahun 2011 mengatur bahwa lembaga yang mengelola zakat adalah Badan Amil Zakat baik tingkat pusat maupun daerah dan lembaga amil zakat swasta. Lembaga amil zakat atau LAZ adalah lembaga yang berfungsi menampung dan mengelola dana zakat, infak dan shodaqoh (Riyanti dan Irianto,2011). Perkembangannya lembaga amil zakat swasta di Indonesia cenderung lebih berkembang karena mengembangkan program -program yang lebih keinginan sesuai dengan kebutuhan dan perkembangan masyarakat.

Indonesia merupakan Negara muslim terbesar sehingga potensi zakat yang dihimpun akan sangat besar. Penelitian pernah dilakukan BAZNAS bekerjasama dengan Fakultas Ekonomi Manajemen (FEM) IPB dan Islamic Development Bank pada tahun 2011, bahwa potensi zakat secara nasional mencapai angka 3,40 persen dari total Produk Domestik Bruto (PDB) yakni potensi zakat nasional sebenarnya kurang lebih mencapai Rp. 217 Triliun pertahun (Majalah Zakat Edisi Mei 2013). Besarnya potensi zakat ini tidak diimbangi dengan realisasi pengumpulan zakat. Pada tahun 2011 berdasarkan data BAZNAS, penerimaan zakat di Indonesia baru sebesar Rp. 1,7 triliun, kemudian penerimaan zakat pada tahun 2012 baru sekitar 1\% dari potensi zakat di Indonesia yaitu Rp. 2,73 triliun. Data ini menunjukkan masih begitu besarnya gap antara potensi zakat dengan realisasi pengumpulan zakat.

Permasalahan realisasi zakat yang masih sangat besar dengan besarnya potensi zakat di Indonesia mendorong LAZ meningkatkan akuntabilitas public sebagaimana dibuktikan dalam survey yang dilakukan UIN Jakarta ( tanpa tahun, dalam www.infozplus.com. hasil survey tersebut menunjukkan agar LAZ bekerja secara akuntabel dan transparan (97\%), tuntutan agar publik diberi akses dan pengawasan terhadap dana yang dikelola (90\%), menuntut publikasi laporan keuangan di media massa (90\%), lalu 88\% perlunya pendataan donatur, adanya keengganan masyarakat untuk menyalurkan ke lembaga zakat yang kurang dikenal akuntabilitasnya (75 \%), bahkan mereka ingin mengetahui kemana zakat diserahkan. Data diatas menujukkan kepercayaan masyarakat terhadap lembaga pengelola zakat yang masih kurang terutama pada kualitas pengelolaan zakat.

Akuntabilitas LAZ menjadi tuntutan publik yang tidak bisa dihindari mengingat yang dikelola oleh LAZ adalah dana publik yang membutuhkan akuntabilitas publik. Huda dan Sawarjuwono (2013) berhasil mengidentifikasi persoalan akuntabilitas yang dihadapi organisasi pengelola zakat/OPZ dengan hasil menunjukkan tumpang tindihnya program pemberdayaan antar OPZ, data muzaki dan mustahik tidak akurat, terbatasnya kemitraan OPZ, kebijakan pemerintah bertentangan dengan program pendayahgunaan, belum didapatkan model promosi murah dan keterbatasan tenaga amil yang profesional.

Akuntabilitas dapat dilakukan dengan menyajikan laporan keuangan zakat yang akuntabel (dapat dipertanggungjawabkan) dan transparan. Undang-Undang No. 23 tahun 2011 tentang Pengelolaan Zakat pada pasal 2 menyatakan pengelolaan zakat berazaskan syariat islam; amanah; kemanfaatan; keadilan; kepastian hukum; dan akuntabilitas. Akuntabilitas LAZ harus diciptakan untuk meningkatkan kepercayaan terhadap LAZ (Nurhasanah, 2018). Akuntabilitas LAZ tidak hanya kepada manusia saja (habluminannas) yaitu kepada muzaki dan stakeholder LAZ tetapi yang utama adalah akuntabilitas kepada Allah Sang Khaliq penguasa tunggal alam semesta (habluminannas). Habluminannas diartikan hubungan dengan sesama manusia itu sendiri dalam hal ini melibatkan aspek mental. Sedangkan Habluminallah adalah hubungan manusia dengan 
Allah yang melibatkan aspek spiritual. Aspek mental menjembatani jalannya aspek fisik dan spiritual.

Penelitian yang dilakukan Triyuwono dan Roekhuddin (2000) pada penelitian sebuah Lazis di Jakarta menyatakan bahwa akuntabilitas meliputi aspek fisik, mental dan spiritual. Aspek fisik berupa laporan keuangan dan atau laporan lainnya yang bersifat kuantitatif, sedangkan aspek mental berwujud laporan pencapaian program program kualitatif yang ditetapkan oleh Dewan Penasihat atau laporan ketaatan dan praktik prinsip etika syariah. Aspek spiritual bersifat abstrak karena perwujudannya melibatkan dimensi spiritual manajemen yaitu sifat ihsan dan takwa yang diwujudkan dalam bentuk ketaatan pada etika syariah dan lebih kongkrit lagi diwujudkan dalam bentuk laporan keuangan dan laporan lain pada tataran fisik. Berdasarkan latar belakang permasalahan tersebut, penelitian ini tentang bagaimana akuntabilitas lembaga amil zakat infak dan sedekah dalam perspektif Sharia'ah Enterprise Theory. Penelitian ini diharapkan berkontribusi membimbing kebijakan Dewan Syariat.

\section{TINJAUAN PUSTAKA}

\section{Akuntabilitas}

Akuntabilitas adalah kewajiban melaporkan dan mempertanggungjawabkan suatu keberhasilan maupun organisasi untuk mencapai misi dan tujuan yang telah direncanakan dilakukan dengan publikasi di media secara berkala. (Mardiasmo,2009). Akuntabilitas dalam perspektif islam berarti pertanggungjawaban seorang manusia kepada Sang Pencipta. Akuntabilitas merupakan cara mempertanggungjawabkan penerima amanah yakni lembaga amil zakat kepada pemberi amanah. Pertanggungjawaban harus dilaksanakan setiap pribadi maupun dalam hal ini organisasi/ lembaga atas segala tindakannya kepada Allah swt. Allah berfirman:

"Sesungguhnya Allah menyuruh kamu menyampaikan amanat kepada yang berhak menerimanya dan (menyuruh kamu) apabila menetapkan hukum di antara manusia supaya kamu menetapkan dengan adil. Sesungguhnya Allah maha memberi pengajaran yang sebaiknya kepadamu. Sesungguhnya Allah adalah Maha Mendengar lagi Maha Melihat." (QS. An-Nisa: 30).

Ayat ini menjelaskan bahwa kewajiban menyampaikan amanat kepada yang berhak menerimanya, artinya kewajiban untuk mempertanggungjawabkan segala sesuatu yang menjadi amanatnya.

Akuntabilitas secara umum adalah bentuk pertanggungjawaban atas kewajiban yang dibebankan kepada seseorang. Dalam pandangan akuntansi akuntabilitas merupakan bentuk pertanggungjwaban akuntan terhadap kebenaran atas laporan keuangan yang dilaporkannya sehingga dapat menghasilkan pengungkapan yang benar (Tapanjeh,2009). Endahwati (2014) mengungkapkan akuntabilitas sebagai bentuk pertanggungjawaban manajemen atau penerima amanah dalam hal ini lazis kepada pemberi amanah atas pengelolaan sumber-sumber daya yang dipercayakan kepadanya baik secara vertikal dan horizontal. Prinsip amanah sebagai prinsip yang ditekankan dalam akuntabilitas vertikal, sedangkan prinsip profesionalisme dan transparansi adalah prinsip yang ditekankan dalam akuntabilitas yang bersifat horizontal.

Akuntabilitas dari sudut pandang syariah sebagaimana diungkapkan oleh Mardiasmo (2002) bahwa akuntabilitas sebagai kewajiban pihak pemegang amanah (dalam hal ini amil) untuk memberikan pertanggungjawaban, menyajikan, melaporkan, mengungkapkan segala aktivitas dan kegiatan yang menjadi tanggung jawabnya kepada pihak pemberi amanah (muzaki) yang memiliki hak dan kewenangan untuk meminta pertanggungjawaban tersebut. Islam telah menjelaskan dalam Al Quran bahwa Allah telah menggariskan bahwa akuntabilitas adalah prinsip akuntansi yang perlu utama. 


\section{Dimensi Akuntabilitas}

Ellwood dalam Mardiasmo (2002) menjelaskan Dimensi akuntabilitas adalah sebagai berikut: Akuntabilitas kejujuran dan akuntabilitas hukum. Akuntabilitas kejujuran berkaitan dengan penghindaran penyalahgunaan jabatan (abuse of power) sedangkan akuntabilitas hukum berupa jaminan kepatuhan terhadap hukum dan peraturan lain yang disyaratkan pada penggunaan sumberdana publik. J.D Stewart dikutip Trijuwono dalam Ulum (2004) dalam tulisannya The Role of Information in Public Accountability sebagaimana menjelaskannya sebagai akuntabilitas atas legalitas dan kejujuran atau ketaatan terhadap undang-undang atau peraturan yang berlaku. Accountability for probity berkaitan dengan penghindaran kejahatan jabatan (malfeasance), lebih ditekankan untuk meyakinkan bahwa dana digunakan dengan cara yang benar. Accountability for probity legality menekankan bahwa kekuasaan yang diberikan oleh undang-undang tidak melampaui batas. Akuntabilitas proses (process accountability) terkait dengan apakah prosedur yang digunakan dalam melaksanakan tugas sudah cukup baik, sesuai sistem informasi akuntansi yang build in control, sistem informasi manajemen. Akuntabilitas proses terwujud melalui pemberian pelayanan publik yang cepat, responsif dan murah biaya.Akuntabilitas program (program accountability) terkait dengan pencapaian tujuan yang ditetapkan dapat dicapai dan penggunaan pertimbangan alternatif program yang memberikan hasil optimal dengan biaya minimal.Akuntabilitas kebijakan (policy accountability) terkait dengan pertanggungjawaban pemerintahn atas kebijakan-kebijakan yang diputuskan pemerintah terhadap DPR/DPRD dan masyarakat luas. Akuntabilitas Kinerja (Performance accountability) merupakan akuntabilitas terhadap pencapaian kegiatan yang efisien.

\section{Akuntabilitas dalam Pandangan SET}

Teori utama pada artikel ini adalah Shariah Enterprise Theory (SET). SET muncul karena Enterprise Theory (ET) cenderung kearah nilai-nilai kapitalisme sehingga perlu bentuk pengembangan yang lebih lanjut agar lebih dekat dengan syariah yang akhirnya memperoleh bentuk dikenal dengan Shari'ah Enterprise Theory (SET) (Triyuwono,2015). SET mengandung nilai-nilai Islam yang telah diinternalisasi dengan memahami bahwa tindakan dasar dalam hubungan manusia dengan alam serta tindakan komunikasi dengan sesama dan tindakan dasar lainnya terkait dengan hubungan manusia dengan penciptanya (Hermawan dan Rini, 2016). Dimensi hubungan akuntabilitas kepada Allah merupakan hubungan yang utama. Dialah pemilik tunggal dan mutlak. Sumberdaya yang dimiliki stakeholder adalah amanah dari Allah yang melekat dengan tanggungjawab untuk memanfaatkannya sesuai cara dan tujuan yang diitetapkan Allah Sang Pemberi Amanah. Keridhoan Allah menjadi tujuan utama dari penggunaan sumberdaya ini. Penempatan Allah sebagai stakeholder yang tertinggi, maka membangkitkan kesadaran ketuhanan pada semua praktik akuntansi syariahnya. Bentuk implementasi akuntabilitas terhadap Allah adalah melalui kegiatan kegiatan LAZIS di bidang keagamaan yang berpedoman pada prinsip syariah (Hermawan dan Rini,2016).

Dimensi hubungan akuntabilitas kedua adalah manusia dengan manusia yang dibedakan menjadi 2 kelompok yaitu direct stakeholders dan indirect stakeholder. Direct stakeholder adalah pihak yang secara langsung memberikan kontribusi kepada perusahaan baik dalam bentuk kontribusi keuangan ataupun non keuangan. Indirect stakeholder adalah pihak yang tidak memberikan kontribusi secara langsung kepada perusahaan, baik keuangan ataupun non keuangan. Golongan stakeholder yang ketiga adalah hubungan akuntabilitas kepada alam (Ekologi). Alam sebagai ekosistem vital yang memberikan kontribusi bagi kelangsungan hidup organisasi. Alam adalah sumberdaya yang diamanahkan Allah untuk dikelola dan dilestarikan.

Akuntabilitas SET merupakan akuntabilitas holistik karena meliputi dimensi hubungan manusia dengan Tuhan (spiritualitas), dimensi hubungan manusia dengan lingkungan alam (akuntabilitas 
ekologi dan sosial) dan dimensi manusia dengan manusia (akuntabilitas ekonomi). Triyuwono dalam Kholmi (2012) menjelaskan konsep akuntabilitas yaitu Allah sebagai pemberi amanah dan prinsip tertinggi manusia, manusia dan alam. Pertanggungjawaban ini dimaknai menjadi habluminallah dan hablumminannas. Penelitian Triyuwono dan Roekhuddin dalam Irianto dan Riyanti (2011) menjelaskan bahwa aspek fisik adalah laporan keuangan dan/atau laporan lainnya, aspek mental dimaknai berupa laporan pencapaian program-program kualitatif yang ditetapkan dewan penasihat atau laporan tentang telah ditaati dan dipraktikannya prinsip prinsip syariah. Aspek spiritual bersifat abstrak dan perwujudannya melibatkan dimensi spiritual manajemen. Akuntabilitas menurut Triyuwono dan Roekhudin (2000) meliputi aspek fisik, mental dan spiritual.

\section{Aspek Akuntabilitas}

Berbagai bentuk akuntabilitas di atas melibatkan aspek fisik, mental dan spiritual (Triyuwono dan Roekhuddin, 2000). Aspek fisik dalam akuntabilitas di atas adalah dalam bentuk laporan keuangan dan laporan lainnya yang secara fisik dapat terlihat dan cenderung bersifat kuantitatif. Akuntabilitas yang hanya melibatkan aspek fisik saja cenderung bebas nilai sehingga penilaiannya hanya untung/rugi secara material dan cenderung kurang humanis. Agar tidak bebas nilai, aspek fisik tersebut harus ditunjang dengan aspek mental dan spiritual. Aspek mental meliputi nilai nilai humanis seseorang yang etis sehingga mengesampingkan ego dan lebih bersifat altruistis. Aspek mental dalam akuntabilitas diwujudkan dalam bentuk laporan kualitatif. Laporan kualitatif yang dimaksud berupa laporan pencapaian program-program yang telah direncanakan, ketaatan pada aturan yang ditetapkan atau penjelasan atas pencapaian materiil dalam laporan kuantitatif yang ada. Aspek mental erat hubungannya dengan laporan pencapaian program program kualitatif yang ditetapkan oleh Dewan Penasihat atau laporan ketaatan dan praktik prinsip etika syariah. Aspek mental tersebut meliputi nilai-nilai humanis seseorang yang etis sehingga mengesampingkan ego dan lebih bersifat altruistis. Menurut Triyuwono dan Roekhuddin (2000), aspek mental dalam akuntabilitas diwujudkan dalam bentuk laporan kualitatif. Laporan kualitatif yang dimaksud berupa laporan pencapaian program-program yang telah direncanakan, ketaatan pada aturan yang ditetapkan atau penjelasan atas pencapaian materiil dalam laporan kuantitatif yang ada. Aspek mental tersebut terkait dengan aspek spiritual yang menekankan pada hubungan manusia dengan Tuhan. Kesadaran dan rasa takut pada Tuhan akan berpengaruh pada mental dan perilaku seseorang, karena ia merasa selalu diawasi olehNya. Hal ini akan membuahkan perilaku etis seseorang termasuk perilaku jujur. Aspek Mental pada LAZIS ini terlihat pada beberapa program baik untuk direct stakeholder dan indirect stakeholder. Pada directstakeholder yaitu amil/ karyawan diimplementasikan pada program kerja pelatihan ESQ, program kepatuhan karyawan terhadap syariat Islam seperti berhijab, pembiasaan tilawah Al-Quran. Pada indirect stakeholder yakni program-program pemberdayaan ekonomi, program dakwah, bedah rumah, beasiswa pelajar dan lain sebagainya. Program program ini akan menguatkan aspek mental. Aspek spiritual berkaitan dengan aspek spiritual yang menekankan pada hubungan manusia dengan Tuhan. Perasaan yakin dan takut pada Tuhan akan berpengaruh pada mental dan perilaku seseorang karena ia merasa selalu diawasi. Menurut Mordhah (2012) konsep akuntabilitas telah jelas diatur dalam Islam beserta mekanismenya telah menjadi sistem yang harus diterapkan dalam aturan organisasi. Akuntabilitas kepada Allah seharusnya menjadi prioritas utama pengelola zakat. Dalam Surah Al Baqoroh:255 yang artinya "Allah mengetahui apa apa yang ada dihadapan mereka dan dibelakang mereka, dan mereka tidak mengetahui apa apa dari ilmu Allah melainkan apa yang dikehendakinya". Aspek spiritual bersifat abstrak dan perwujudannya melibatkan dimensi spiritual manajemen seperti ikhsan dalam bekerja dan program-program kerja LPZ bermuatan spiritual bagi direct stakeholder dan indirect stakehoder. Amerieska, dkk. 
(2012) menyatakan bahwa akuntabilitas spiritual sering dikatakan sebagai akuntabilitas internal dari dalam diri manusia itu sendiri. Dapat dikatakan juga akuntabilitas seseorang kepada Tuhannya. Akuntabilitas spiritual meliputi pertanggungjawaban LPZ dalam program kerja LPZ yang bermuatan spiritual. Penelitian Riyanti dan Irianto, aspek spiritual dijelaskan dengan pembahasan akuntabilitas kejujuran yang dibuktikan dengan adanya bukti transaksi dalam setiap transaksi dan laporan pertanggungjawaban setiap adanya event. Bentuk lain program spiritual pada beberapa LAZIS diwujudkan dengan;program keimanan dan ketaqwaan kepada Tuhan sebagai pencipta, pemelihara, dan pelebur alam semesta; tuntutan bekarja adalah ibadah sehingga perilaku karyawan harus berdasarkan norma-norma, nilai-nilai dan aturan yang bersumber dalam ajaran agama dan berbagai konsensus dan kesepakatan manusia; memandang pelayanan kepada sesama makhluk ciptaan Tuhan dengan semangat saling memberi (gotong-royong); kesempatan menjalankan ibadah bagi karyawan; kontribusi bidang keagamaan lainnya seperti pembenahan masjid, pembelian mesin genset untuk masjid, pembelian TOA untuk masjid, bantuan untuk pelaksanaan tilawatil quran, pemberian pelatihan tenaga dakwah agar masyarakat semakin termotivasi dengan ibadah.

\section{Lembaga Amil Zakat Infak dan Sedekah}

Tata kelola Lembaga amil zakat infak dan Sedekah (LAZIS) di Indonesia diatur dalam UndangUndang No.23 Tahun 2011 tentang Pengelolaan Zakat dan Keputusan Menteri Agama (KMA) No. 333 Tahun 2015 tentang Pedoman Pemberian Izin Pembentukan Lembaga Amil Zakat. Peraturan baru ini akan mendorong tata kelola Lembaga amil zakat yang lebih transparan dan akuntabel. Peraturan lain diatur dalam Undang-Undang No.23 Tahun 2011 tentang pengelolaan zakat di Indonesia. Regulasi tersebut akan menyeragamkan tata kelola zakat di Indonesia.

\section{PSAK 109}

Pernyataan Standar Akuntansi Keuangan Nomor 109 tentang Akuntansi Zakat dan Infak/Sedekah bertujuan untuk mengatur pengakuan, pengukuran, penyajian dan pengungkapan transaksi zakat dan infaq/sedekah. Pernyataan ini berlaku untuk amil yang menerima dan menyalurkan zakat dan infak/sedekah (IAI, 2015). Unsur-unsur dalam laporan keuangan organisasi nirlaba berdasarkan PSAK No. 45, meliputi: Laporan Posisi Keuangan, Laporan Perubahan Dana, Laporan Perubahan Aset Kelolaan, Laporan Arus Kas Entitas, Catatan Atas Laporan Keuangan.

\section{METODE PENELITIAN}

Penelitian ini adalah penelitian kualitatif yang bersifat studi literatur (literature research) yang menggunakan buku-buku dan literatur-literatur terkait. Pada penelitian ini ditelusuri berbagai buku dan literatur terkait dengan akuntabilitas Lembaga amil zakat. kemudian dari berbagai literatur tersebut dipergunakan untuk membahas bagaimana implementasi akuntabilitas dalam pandangan shari'ah enterprise theory. Tujuannya untuk memberikan penjelasan yang komprehensif tentang implementasi akuntabilitas pada Lazis dalam perspektif SET. Data yang digunakan dalam penelitian ini adalah data sekunder berupa buku tentang zakat, website lain, jurnal yang relevan.

\section{PEMBAHASAN}

\section{Akuntabilitas Holistik dalam Pandangan Shari'ah Enterprise Theory}

Akuntabilitas dalam pandangan Shari'ah Enterprise Theory menjelaskan dimensi hubungan akuntabilitas kepada Allah merupakan hubungan yang utama. Allah sebagai pemilik tunggal di alam semesta ini. Pada Hakikatnya sumber daya adalah milik Allah. Adapun sumberdaya yang 
dimiliki stakeholder adalah amanah dari Allah. LAZIS mempunyai tanggungjawab untuk memanfaatkannya sesuai cara dan tujuan yang diitetapkan Allah Sang Pemberi Amanah. Tujuan pengelolaaan sumberdaya itu adalah untuk kesejahteraan umat manusia.

Shari'ah Enterprise Theory mengenal trilogi dimensi hubungan akuntabilitas yang mengacu kepada Tuhan sebagai pusat dari akuntabilitas, akuntabilitas kedua adalah manusia kepada manusia yang mana masih dikategorikan dalam dua bentuk (direct dan indirect stakeholder) dan yang terakhir adalah alam, maka dari itu SET akan lebih sesuai untuk dijadikan alat analisis untuk memahami praktik akuntabilitas.

\section{Aspek Akuntabilitas}

\section{Akuntabilitas Kejujuran}

LAZIS sebagai lembaga Islam sangat menjunjung tinggi aturan syariah, terlebih lagi dana yang dikelola adalah dana publik/ umat. Implementasi dari akuntabilitas vertikal pada Allah swt dalam konteks habluminallah ini dapat terlihat secara fisik melalui penulisan transaksi yang jujur, kebijakan program dan lain sebagainya. Salah satu bentuk transparansi LAZIS diwujudkan dalam bentuk laporan pertanggungjawaban yang dipublikasikan di website. Implementasi akuntabilitas kejujuran tercermin pada pembiasaan akhlak mulia pada karyawan dengan mengedepankan sikap jujur dalam segala hal. Bentuk-bentuk kejujuran tersebut dapat dikatakan sebagai akuntabilitas kejujuran yang oleh Ellwood dalam Mardiasmo (2002) dikatakan sebagai akuntabilitas yang terkait dnegan penghindaran penyalahgunaan jabatan (abuse of power).

\section{Akuntabilitas Hukum}

Akuntabilitas Hukum diimplementasikan dengan ketaatan terhadap hukum syariah seperti aturan penggunaan pakaian syar'i bagi karyawan perempuan dan larangan merokok bagi karyawan laki- laki, menghidupkan sunnah Rasul dan aturan lain yang mengimplementasikan aspek ketaatan terhadap syariat. Kepatuhan pada aturan-aturan syariah tersebut juga dapat digolongkan dalam akuntabilitas hukum yang oleh Ellwood dalam Mardiasmo (2002) dikatakan sebagai jaminan adanya kepatuhan terhadap hukum dan peraturan lain yang yang disyaratkan dalam penggunaan sumber dana publik. Kepatuhan karyawan secara individu pada hukum agama yang diyakini tersebut akan berdampak pada kinerja organisasi secara keseluruhan karena organisasi adalah kumpulan dari individu dan kumpulan individu yang baik akan menjadikan organisasi tersebut juga baik dalam kinerjanya mengelola dana umat.

\section{Akuntabilitas Program dan Kebijakan}

Akuntabilitas Program dan kebijakan yang menunjukkan akuntabilitas dalam konteks habluminallah. adalah dibuatnya program-program yang tidak melanggar aturan syari'ah seperti mengadakan survey bagi mustahik zakat apakah termasuk 8 asnaf. Akuntabilitas horisontal adalah akuntabilitas dalam konteks habluminannas (hubungan manusia dengan manusia). Dalam konteks ini juga terdapat istilah akuntabilitas vertikal dalam arti akuntabilitas manusia kepada 
manusia lain yang secara hirarki organisasi lebih tinggi. Dalam kehidupan organisasi, akuntabilitas ini terjadi secara internal dan eksternal organisasi. Secara internal adalah pertanggungjawaban individu dalam organisasi sesuai hirarki dalam struktur organisasi tersebut. Secara eksternal adalah pertanggungjawaban Lazis pada Pemerintah sebagaimana diatur dalam UU No. 28 Tahun 2004. Selain akuntabilitas vertikal dalam konteks habluminannas, juga terdapat akuntabilitas secara horisontal pada pihak-pihak diluar hirarki organisasi tetapi mempunyai kepentingan langsung terhadap organisasi. Berdasarkan pihak-pihak yang berkepentingan (stakeholder), LAZIS memiliki direct dan indirect participant (Triyuwono, 2015). Direct participant adalah pihak yang berkontribusi secara langsung pada LAZIS berupa materi maupun nonmateri yaitu para donatur dan sumber daya manusia LAZIS itu sendiri baik di pusat maupun cabang. Sedangkan indirect participant adalah pihak yang sama sekali tidak memberikan kontribusi pada LAZIS namun tetap memiliki hak atas keberadaan organisasi tersebut yang dalam hal ini adalah muztahik dan alam. Akuntabilitas pada masing-masing pihak tersebut adalah sebagai berikut: Pemerintah berkewajiban untuk melakukan akuntabilitas vertikal secara internal organisasi dalam bentuk laporan tertulis maupun lisan secara rutin tiap bulan maupun pada akhir tahun. Donatur adalah orang yang secara tetap memberikan sumbangan berupa uang kepada suatu perkumpulan dan sebagainya (KBBI, 2002). Donatur terdiri dari donatur perorangan murni maupun donatur perorangan yang dikoordinir oleh instansi. tempat donatur bekerja. Lingkungan/alam tergolong prinsipal Lazis karena alam adalah sumberdaya yang Allah amanahkan untuk dijaga dan dikelola kepada pengelola Lazis. Pengelola Lazis sangat concern terhadap pelestarian alam maupun program tanggap bencana. Akuntabilitas terhadap alam disebut akuntabilitas ekologis. Bentuk akuntabilitas ekologis dalam bentuk program tanggap bencana dan pelestarian alam seperti pemanfaatan limbah dan program reboisasi.

\section{KESIMPULAN}

Berdasarkan hasil dan pembahasan disimpulkan sebagai berikut;a) akuntabilitas tidak hanya menyangkut aspek fisik yang bersifat kuantitatif saja tetapi tidak kalah penting aspek spiritual dan mental. Akuntabilitas yang hanya melibatkan aspek fisik saja cenderung bebas nilai sehingga penilaiannya hanya untung/ rugi secara material dan cenderung kurang humanis. Agar tidak bebas nilai, aspek fisik tersebut harus ditunjang dengan aspek mental dan spiritual. Beberapa hal yang menjadi keterbatasan dalam artikel ini adalah terbatasnya jurnal dan literatur lainnya yang dapat menjelaskan lebih dalam lagi. Saran untuk penelitian selanjutnya, penulis berharap topik ini mampu dikembangkan menjadi penelitian yang lebih mendalam dengan cara melihat langsung fenomena yang terjadi pada LAZIS. Penelitian ini diharapkan mampu digunakan pihak manajemen LAZIS untuk membuat program-program yang menyeimbangkan aspek material dan 
non material dan penelitian ini menambah pemahaman kepada dunia akademik pentingnya pemahaman di bidang akuntansi syariah dan implementasinya di lembaga amil zakat.

\section{DAFTAR PUSTAKA}

Adlan, Aqim M. (2010). Perbandinan Antara Akuntansi Konvensional dan Akuntansi Syariah. Artikel Keislaman.www.infopesantren.web.id/ ppssnh.malang/cgi bin/content.cgi/artikel/index.idx. diakses 29 Juli 2020

Affandi, Didied P, Irianto, G dan Amerieska, S. (2012). Akuntabilitas Pada BMT Ditinjau dari Perspektif Shari'ah Enterprise Theory. Jurnal Ekonomi dan Keuangan Indonesia 2 (1): 2739.

Al-Qur'an. (2005). Departemen Agama RI, Yayasan Penyelenggara Penerjemah/ Penafsir Al Qur'an.Al-Qur'an dan Terjemahannya, Bandung: PT Syaamil Cipta Media.

Ellwood, Sheilla. (1993). Parish Town Councils: Financial Accountability and Management. Local Government Studies 19

Endahwati,YD. (2014). Akuntabilitas Pengelolaan Zakat Infak dan Shadaqah. Jurnal Ilmiah Akuntansi dan Humaniora JINAH 4 (1): 1356-1379

Huda, Nurul \& Suwarjuwono, Tjiptohadi. (2013). Akuntabilitas Pengelolaan Zakat Melalui Pendekatan Modifikasi Action Research, Jurnal Akuntansi Multiparadigma (JAMAL) $4(3), 330-507$

Ikatan Akuntan indonesia. (2015). Pernyataan Standar Akuntansi Keuangan Nomor 109. Jakarta:IAI

Irianto, Gugus dan Riyanti Yudha Rubi. (2011). Jurnal Ekonomi \& Keuangan Islam. Vol 1(2), 169180

Mardiasmo. (2015). Akuntansi Sektor Publik. Yogyakarta: Andi.

Mordhah, N. (2012). Self-Accountabiliy: The Link Between Self-Accountability and Accountability in Islam. International Journal of Humanities and Social Science 5(2):240-245

Puspitasari, Dania. (2011). Fenomenologi Praktik Akuntabilitas BMH (Baitul Maal Hidayatullah) Cabang Malang dalam Perspektif Syari'ah Enterprise Theory). Tesis tidak dipublikasikan Program Magister Pascasarjana Fakultas Ekonomi dan Bisnis Universitas Brawijaya Malang.

Riyanti,Y.B dan Irianto, G. (2011). Akuntabilitas pada Lembaga Amil Zakat.Jurnal Ekonomi Keuangan Indonesia 1(2):169-180

Singandaru, Adhitya Bagus. (2011). Efektivitas Badan Amil Zakat ( BAZ) dalam Mengelola Zakat, Infaq, dan Shadaqah. Tesis tidak dipublikasikan Program Magister Pascasarjana Fakultas Ekonomi dan Bisnis Universitas Brawijaya Malang.

Tapanjeh, Abdussalam Mohammed Abu. (2009). Corporate Governance from the Islamic

Triyuwono,I dan Roekhuddin. (2002). Konsistensi Praktik Sistem Pengendalian Intern dan Akuntabilitas pada Lazis (studi kasus di Lazis X Jakarta). Jurnal Riset Akuntansi Indonesia $3(2)$

Triyuwono,I. (2015). Akuntansi Syariah Perspektif, Metodologi dan Teori Edisi 2-3, Jakarta:Rajawali Pers.

Ulum, I. (2004). Akuntansi Sekor Publik: Sebuah Pengantar. Malang: UMM Press

Undang-Undang No. 23 Tahun 2011 Tentang Pengelolaan Zakat. 
Jurnal Ekonomi, Bisnis dan Akuntansi (JEBA) Volume 22 No 9 Tahun 2020

Majalah Zakat Edisi Mei 2013, BAZNAS, www.pusat.baznas.go.id

www.antaranews.com/berita/371882/potensi-zakat-indonesia-baru-terserapsatu-persen senin, 29 april 2013, diakses 21 Mei 2020 